\title{
„ANKIETA DUSZPASTERSKA Z 1930 R.” ORAZ „SPRAWOZDANIE DUSZPASTERSKIE ZA ROK 1930” I ICH ROLA W PLANACH ODNOWY ŻYCIA SPOLECZNO-RELIGIJNEGO W DIECEZJI KIELECKIEJ W OKRESIE MIĘDZYWOJENNYM
}

\begin{abstract}
Streszczenie
Tematem artykułu jest omówienie zachowanych fragmentów dwóch badań ankietowych przeprowadzonych w diecezji kieleckiej w latach 1930-1931, w kontekście wprowadzanej po I wojnie światowej odnowy życia religijnego na jej terenie. Podejmowane w tym zakresie działania po 1918 r. znalazły najpełniejszy wyraz w postanowieniach synodu diecezjalnego z 1927 r. Jednym $\mathrm{z}$ jego elementów było prowadzenie systematycznych obserwacji zmian społeczno-religijnych poprzez powołanie w kurii Komisji wiary i obyczajów, która miała czuwać nad realizacją odnowy synodalnej w diecezji. Między innymi na podstawie prowadzonych badań ankietowych miała ona wskazywać potrzeby w zakresie duszpasterstwa na poziomie całej diecezji i poszczególnych parafii. Jednak wraz z rozwojem ogólnopolskiego programu odnowy życia religijnego opartego na ponaddiecezjalnej organizacji, jaką była Akcja Katolicka, wcześniejszy lokalny projekt nie był kontynuowany, a omawiane dwa badania ankietowe stanowią jego najobszerniejsze, choć nie w pełni zachowane świadectwa.
\end{abstract}

Słowa kluczowe: diecezja kielecka; ankieta duszpasterska; międzywojnie; ks. Zygmunt Pilch; życie społeczno-religijne

\section{Wstęp}

Okres międzywojenny był w Kościele katolickim w Polsce czasem licznych inicjatyw w zakresie wprowadzania metodycznego, opartego na osiągnięciach współczesnych nauk, duszpasterstwa. Jedną z pierwszych ważnych prób zasto-

* Ks. Grzegorz Bujak - dr hab. historii, prof. KUL, Instytut Historii, Katolicki Uniwersytet Lubelski Jana Pawła II, e-mail: grzegorz.bujak@kul.pl

https://orcid.org/0000-0003-2298-2757 
sowania osiągnięć socjologii do interpretacji problemów związanych z duszpasterstwem znajdujemy w pracy ks. F. Mirka ${ }^{1}$ z 1928 r. z przedmową Floriana Znanieckiego. Była ona niewątpliwie punktem zwrotnym $w$ otwieraniu duszpasterstwa na osiągnięcia socjologii $\mathrm{i}$ jej metody analiz sytuacji wiernych $\mathrm{i}$ ich potrzeb, tak religijnych, jak i społecznych. Jednak stopniowe przenikanie osiągnięć nauk świeckich do analizy faktów z zakresu życia religijnego i duszpasterstwa miało miejsce już wcześniej. Sprzyjało temu odbywanie przez wielu księży, jeszcze w okresie przed I wojną światową, studiów teologicznych w zachodnich uczelniach, gdzie zapoznawali się oni z nowymi tendencjami w duszpasterstwie i starali się je twórczo spożytkować w swoich diecezjach ${ }^{2}$. Ważną rolę w rozwoju i popularyzacji tych poglądów wśród niższego kleru odgrywały zjazdy i kursy dla duchowieństwa, organizowane szczególnie intensywnie już od końca I wojny światowej ${ }^{3}$.

Decydujący wpływ na kierunki odnowy życia społeczno-religijnego w diecezji kieleckiej, szczególnie intensywnie rozwijane z końcem I wojny światowej, wywierała silna osobowość jej ordynariusza bpa Augustyna Łosińskiego. Jako wzór do naśladowania stawiał on księżom kieleckim osiągnięcia duchowieństwa poznańskiego, którego przedstawicieli chętnie zapraszał do Kielc z prelekcjami i szkoleniami jeszcze w roku $1917^{4}$. Równocześnie bp. A. Łosiński strzegł swojej niezależności i samodzielności w podejmowaniu wszelkich decyzji dotyczących przemian w diecezji. Na tym tle dochodziło wielokrotnie do napięć w relacjach z Konferencją Episkopatu Polski, której znaczenie wzrastało w niepodległej Polsce $^{5}$.

Środowisko księży kieleckich wydało w okresie międzywojennym wielu społeczników i zwolenników stosowania nowych metod w duszpasterstwie. Wśród nich na uwagę zasługuje postać ks. Zygmunta Pilcha. Wykształcony w Innsbruc$\mathrm{ku}$, po powrocie do diecezji podejmował wielokierunkowe działania w celu odnowienia duszpasterstwa w diecezji kieleckiej, w czym cieszył się całkowitym poparciem i zaufaniem miejscowego ordynariusza. To on pośredniczył w kontaktach ze środowiskiem księży poznańskich, organizował zjazdy duszpasterskie $\mathrm{z}$ ich udziałem w Kielcach i sam uczestniczył w takich zjazdach organizowanych w Poznaniu'.

\footnotetext{
${ }^{1}$ F. Mirek, Elementy społeczne parafii rzymsko-katolickiej. Wstęp do socjologii parafii, Poznań 1928.

${ }^{2}$ A.L. Szafrański, Zarys dziejów teologii pastoralnej ogólnej (hodogetyki), w: Dzieje teologii katolickiej w Polsce, t. 3: wiek XIX i XX, cz. 2, red. M. Rechowicz, Lublin 1977, s. 30-41.

${ }^{3}$ D. Olszewski, Ks. Zygmunt Pilch (1882-1962). Ogólnopolska działalność naukowa kieleckiego homilety, w: Kielce i kielczanie w XIX i XX wieku, red. U. Oettingen, Kielce 2005, s. 443-446.

${ }^{4}$ G. Liebrecht, Biskup Augustyn Losiński. Ordynariusz diecezji kieleckiej w latach 1910-1937, Kielce 2018, s. 124-125.

${ }^{5}$ K. Krasowski, Biskupi katoliccy II Rzeczypospolitej. Słownik biograficzny, Poznań 1996, s. 151.

${ }^{6}$ W. Zamojski, Potrzeba czasu, „Przegląd Diecezjalny”, 5 (1917-1918) nr 1, s. 11-16; Sprawozdanie ze zjazdu duszpasterskiego, „Przegląd Diecezjalny”, 11 (1924) nr 11-12, s. 246-251.
} 
Jako promotor synodu kieleckiego z 1927 r. wniósł decydujący wkład w jego przygotowanie i opracowanie statutów synodalnych, w których sformułowane zostały główne kierunki odnowy duszpasterskiej w diecezji. Program odnowy życia społeczno-religijnego wiernych świeckich został zawarty w rozdziale statutów pt. $O$ wierze i obyczajach osób świeckich ${ }^{7}$. Omówione w nich zostały przyczyny rozwoju zjawisk negatywnych, środki zaradcze oraz wymagania kierowane pod adresem księży, którzy mieli w parafiach realizować synodalny program odnowy duszpasterskiej.

W statucie 109 synod kielecki wskazywał cel tej odnowy:

Duszpasterze będą się starali w naukach stanowych, stowarzyszeniach ojców, matek, na zebraniach rodzicielskich i przy każdej sposobności przypominać zasady moralności chrześcijańskiej, będą pracowali, napominali i nakłaniali, aby te zasady stały się normą postępowania dla wiernych.

Szczegółowo obowiązki duszpasterzy zostały rozwinięte w liczącej prawie 20 stron części piątej statutów: Praca pasterska9.

Choć nie zostało to powiedziane wprost, realizację programu odnowy społeczno-religijnej nakreślonej w statutach synodu z 1927 r. miała realizować i kontrolować Komisja wiary i obyczajów. W statucie 93 synod stwierdzał:

dla obrony wiary i moralności, dla zapobieżenia odszczepieństwom i herezjom, dla propagandy wiary i umoralniania wiernych istnieje w diecezji Komisja wiary i obyczajów zwana inaczej Commissio Vigilantiae.

Natomiast w statucie 21 wymieniającym instytucje kurialne określono Komisję wiary i obyczajów jako „będącą jednocześnie (w myśl encykliki Pascendi) Concilium Vigilantiae i radą kaznodziejską". Zakreślone w ten sposób kompetencje komisji dawały jej bardzo rozległe uprawnienia w wielu obszarach życia diecezjalnego.

Mimo podjętych w statutach 21 i 93 prób utożsamienia Komisji wiary i obyczajów z istniejącą od czasów Piusa X komisją Concilium Vigilantiae, nie było to takie proste. Dopiero w rubryceli z $1931 \mathrm{r}^{10}{ }^{10}$ w strukturze kurii pojawiła się nowa Komisja wiary i obyczajów obok wymienianej nieprzerwanie w elenchusach komisji Concilium Vigilantiae. Na czele Komisji Wiary i Obyczajów formalnie, jak na czele każdej komisji kurialnej, stał biskup ordynariusz, a jego zastępcą i praktycznym jej zwierzchnikiem został mianowany ks. Z. Pilch. Jedynym członkiem nowej Komisji wiary i obyczajów był ks. Mikołaj Łapot, podczas gdy Concilium Vigilantiae występowało w spisach kurialnych instytucji od lat 20 . w stałym składzie pięciu członków. O ile bowiem biskup mógł swobodnie utworzyć dowolną komisję w składzie kurii, formalnej likwidacji komisji o nazwie Concilium Vigilantiae ustanowionej na mocy autorytetu papieskiego sprzeciwiały się przepisy

${ }^{7}$ Synodus dioecesana kielcensis 1927, Kielce b.r.w., stat. 87-124.

${ }^{8}$ G. Bujak, Synody diecezjalne Kościoła katolickiego w Polsce w latach 1922-1931. Organizacja i problematyka uchwat, Kielce 2010, s. 149-160.

${ }^{9}$ Synodus dioecesana, s. 204-222.

${ }^{10}$ Elenchus venerabilis cleri saecularis ac regularis dioecesis kielcensis (dalej: Elenchus), (1931), s. 14-18. 
prawa kościelnego ${ }^{11}$. Sytuacja była skomplikowana, gdyż - o czym będzie jeszcze mowa - ks. Z. Pilch jako wiceprzewodniczący Komisji wiary i obyczajów występował już na spotkaniu dziekanów w listopadzie 1929 r. Obie komisje: wiary i obyczajów i Concilium Vigilantiae istniały obok siebie w składzie kurii aż do czasów reformy, przeprowadzonej przez nowego ordynariusza bpa Czesława Kaczmarka, który po swoim przyjściu do diecezji w roku 1938 zlikwidował Komisję wiary i obyczajów, a zachował komisję Concilium Vigilantiae ${ }^{12}$.

Z inicjatywy Komisji wiary i obyczajów przeprowadzono w latach 1930-1931 dwa ważne badania ankietowe w całej diecezji: „Ankietę duszpasterską z 1930 r.” oraz „Sprawozdanie duszpasterskie za rok 1930”. Oba badania były próbą zastosowania elementów analizy socjologicznej do celów duszpasterskich. Zebrane w ten sposób informacje miały służyć tworzeniu diecezjalnych planów działań duszpasterskich zmierzających do odnowienia życia społeczno-religijnego w duchu programu nakreślonego na synodzie. W ten sposób została także wyznaczona linia rozwoju reformy duszpasterskiej: od analizy stanu religijno-moralnego wiernych, poprzez ocenę potrzeb i możliwości lokalnych wspólnot parafialnych i organizacji grupujących świeckich, do formułowania konkretnych posunięć i inicjatyw duszpasterskich dla całej diecezji kieleckiej.

\section{Ankieta duszpasterska z 1930 r.}

Ankieta duszpasterska z 1930 r. była pierwszą w diecezji tak szeroko zakrojoną inicjatywą o charakterze badawczym mającą za zadanie poznanie stanu religijnego i moralnego wiernych w celu wykorzystania zgromadzonych informacji w planowaniu działań duszpasterskich w diecezji.

Jej przeprowadzenie zapowiedział ks. Z. Pilch na posiedzeniu księży dziekanów diecezji kieleckiej 21 listopada 1929 r. W referacie pt.: Najbliższe prace Komisji wiary i obyczajów ks. Z. Pilch wskazywał, że celem działalności komisji jest ,podnoszenie i wzmacnianie wiary w masach katolickich”. Żeby móc odpowiednio realizować te zadania „trzeba przede wszystkim zbadać istniejące słabości i przyczyny niewiary”. Poinformował zebranych, że w tym celu, do każdego księdza proboszcza zostanie przesłana odpowiednia ankieta, którą „wykonać trzeba będzie ściśle i skrupulatnie"13.

Nie przygotowano jednak odrębnego, drukowanego formularza ankiety, a jedynie na łamach miesięcznika „Kielecki Przegląd Diecezjalny” ze stycznia 1930 r. został opublikowany zestaw pytań ankietowych, na które księża proboszczowie mieli odpowiedzieć. Ogłaszając ankietę, ks. Z. Pilch informował księży, że realizując swoje zadania, Komisja wiary i obyczajów: „chce swą działalność oprzeć na gruncie realnym, to znaczy, chce się przede wszystkim zapoznać z terenem pracy"14. Następnie wyjaśniał, że co prawda różne komisje kurialne gromadzą in-

${ }^{11}$ I. Grabowski, Prawo kanoniczne, Warszawa 1947, s. 224-226, 465.

${ }^{12}$ Elenchus, (1940-1941), s. 14-19.

${ }^{13}$ Sprawozdanie z konferencji Ks.Ks. Dziekanów odbytej pod przewodnictwem Najdostojniejszego Arcypasterza z Kielcach 21 listopada 1929 r., „Kielecki Przegląd Diecezjalny” (dalej: KPD), 16 (1929) nr 12, s. 296.

${ }^{14}$ Ankieta Duszpasterska, KPD, 16 (1930) nr 1, s. 12 
formacje z wielu różnych działów duszpasterstwa, to jednak „powstał długi sznur pytań, który będzie wymagał pewnego wysiłku autorskiego od W.W. Duszpasterzy”. Zwracał uwagę, że „,ankieta wtedy ma wartość, jeśli jest pełna, zwłaszcza gdy się ją po raz pierwszy przeprowadza" 15 .

Autor miał świadomość, że przeprowadzana ankieta wykracza poza zakres zwykłych obowiązków proboszczów i będzie od nich wymagała dodatkowego, znacznego wysiłku w celu zgromadzenia odpowiednich materiałów i przygotowania wyczerpujących odpowiedzi. Dlatego apelował do ich poczucia obowiązku i odwoływał się do „gorliwości duszpasterskiej”. Podkreślał, że wynik ankiety „może być w wielu punktach rewelacjąa" i zapowiadał zapoznanie księży z jej wynikami w odpowiednim czasie. Równocześnie jednak zaznaczył, co zostało w tekście specjalnie wyróżnione pogrubioną czcionką, że „ankieta ma charakter urzędowy i dlatego odpowiedź na nią nadeślą wszyscy Księża proboszczowie"16.

Zachęcał do obszernych wypowiedzi wykraczających poza wymagany zakres:

W.W. Ks.Ks. nie tylko mogą, lecz powinni wyrazić, przy poszczególnych działach swe doświadczenia, dezyderaty i uwagi. Bardzo nam zależy na zebraniu obfitych i życiowych materiałów.

Proponował również, aby księża zabierali głos w odniesieniu do tematów poruszonych $\mathrm{w}$ ankiecie i pisali artykuły, które miały być drukowane na łamach KPD, a także dyskutowali o nich podczas konferencji dekanalnych ${ }^{17}$.

Z przytoczonych wypowiedzi ks. Z. Pilcha wynika, że swoją inicjatywę widział on jako swoiste pospolite ruszenie kleru, mające wywołać powszechną i głęboką refleksję nad prowadzoną działalnością duszpasterską. Termin nadsyłania odpowiedzi został wyznaczony na koniec lutego 1930 r. Krótki termin przygotowania odpowiedzi na ankietę pokrywał się z okresem wzmożonych obowiązków księży w parafiach związanym z cyklem roku liturgicznego i odbywaniem kolędy w trudnych zimowych warunkach. Był zatem wyjątkowo niefortunny dla realizacji tak nowatorskiego i obszernego przedsięwzięcia.

Ankieta składała się z 11 obszernych działów problemowych: 1. życie społeczne i obyczajowe, 2. niewiara i sekciarstwo, 3. moralność rodzinna, 4. młodzież, 5. świętowanie, 6. nabożeństwa, 7. śpiew religijny, 8. przystępowanie do sakramentów świętych, 9. życie duchowne wiernych, 10. Słowo Boże, 11. czytelnictwo ${ }^{18}$.

W ramach każdego z tych zagadnień zamieszczono od 4 (życie wiernych) do 11 (młodzież) pytań szczegółowych. Ponadto dział Słowo Boże został podzielony dodatkowo na trzy podgrupy pytań zatytułowane: A. kazania, B. rekolekcje, C. misje. Dział dotyczący rekolekcji zawierał trzy pytania, pozostałe po cztery.

Cała ankieta liczyła w sumie ponad 100 pytań, gdyż niektóre z nich zawierały wymóg udzielenia dodatkowych informacji. Polegało to na tym, że najczęściej po pytaniu o charakterze ogólnym następowało pytanie dodatkowe dotyczące okre-

\footnotetext{
${ }^{15}$ Tamże, s. 13.

16 Tamże.

17 Tamże.

${ }^{18}$ Tamże, s. 13-19.
} 
ślenia skali problemu (ile?, ile razy?). Nierzadko jednak takie dodatkowe pytanie wymagało obszernego dopowiedzenia, które pod względem merytorycznym stanowiło wręcz osobne zagadnienie. Na przykład w dziale nabożeństwa jedno z pytań brzmiało: „Jaka ilość parafian nieregularnie (n.p. co drugą niedzielę) chodzi do kościoła? (dlaczego?)".

Niektóre pytania sugerowały oczekiwane odpowiedzi. Na przykład w dziale „świętowanie”, po serii pytań dotyczących różnych, wyszczególnionych zagrożeń katolickiego świętowania niedzieli, zamieszczono dodatkowe pytanie wymagające omówienia: „w jakim stopniu uroczystości weselne, urządzane w soboty, wpływają na opuszczenie przez weselników w niedzielę mszy św.?".

Mimo skomplikowanej i niespójnej konstrukcji, ankieta mogła być cennym źródłem poznania postaw i poglądów religijnych wiernych diecezji kieleckiej u progu lat 30. XX wieku. Z samego zestawu pytań możemy wnioskować o tym, jaką wagę przykładano w kurii do różnych aspektów duszpasterstwa oraz zagrożeń dla życia moralnego i religijnego wiernych.

Ankieta wskazuje na znaczne oczekiwania autora w stosunku do księży, wymagające niekiedy specjalistycznego przygotowania, którego w większości duchowni nie posiadali. Nic zatem dziwnego, że ankieta spotkała się z oporem z ich strony, mimo że większość z nich ostatecznie przesłała wymagane odpowiedzi. Oryginały nadsyłanych odpowiedzi nie zachowały się. Wyniki ankiety znamy $\mathrm{z}$ omówienia ich fragmentów przez ks. W. Gielniewskiego na łamach KPD ${ }^{19}$. Oba artykuły nie wnoszą jednak istotnych ustaleń związanych z samym procesem przeprowadzania ankiety.

W całości, choć nie w postaci oryginałów ankiet, zachowały się odpowiedzi dotyczące działu trzeciego ankiety: „moralność rodzinna”. Ten fragment nadesłanych z parafii materiałów został - najprawdopodobniej jeszcze w okresie międzywojennym - przepisany na maszynie w formie kartoteki, w której na osobnych kartach zestawiono odpowiedzi z poszczególnych parafii. Karty zostały w lewym górnym rogu zaopatrzone informacją o nazwie parafii, dekanatu i nazwisku proboszcza oraz ułożone dekanatami, a w nich w porządku alfabetycznym nazw parafii. Najprawdopodobniej kartotekę sporządził ks. Z. Pilch, chociaż nie można wykluczyć, że ktoś mu w tym pomagał, o czym może świadczyć fakt posługiwania się trzema różnymi maszynami do pisania.

Kartoteka ta znajduje się w Archiwum Diecezjalnym w Kielcach jako osobna jednostka archiwalna o sygn. OD $17 / 4^{20}$. Ma ona kształt związanego z lewej strony pliku poziomo zorientowanych 207 kart formatu zbliżonego do A5. Karty są numerowane ołówkiem, co - jak można sądzić - dokonano w toku opracowywania materiałów w archiwum. Dokument nie posiada karty tytułowej, ale pierwsza jego karta zawiera wykaz pytań, których treść, kolejność, a nawet numeracja są

${ }^{19}$ E. Gielniewski, Stan religijno-moralny młodzieży w parafiach naszej diecezji na podstawie materiałów z ankiety duszpasterskiej z 1930 r., KPD, 18 (1931) nr 12, s. 307-315; tenże, Wady naszego Ludu w świetle duszpasterskiej ankiety zebranej w początkach ub. roku, KPD, 18 (1931) nr 5, s. 141-144.

${ }^{20}$ Archiwum Diecezjalne w Kielcach (ADK), Akta Kurialne Ogólne, Ankieta duszpasterska dotycząca moralności rodzinnej r. 1920-1029, sygn. OD 17/4. 
dokładnym powtórzeniem części trzeciej formularza ankiety duszpasterskiej opublikowanego na łamach KPD z 1930 r. dotyczącej moralności:

a) Czy się w parafii zaznacza spadek urodzin i w jakim stopniu? (podać liczbę urodzonych w r. 1914, 1920, 25, 26, 27, 28, 29).

b) W ewentualnym spadku urodzeń jakie przeważają względy: moralne (obniżenie się moralności)? czy materialne (kryzys ekonomiczny).

c) Czy idzie jaka propaganda za unikaniem potomstwa i w jakich formach?

d) Czy się słyszy o praktykach procurationis abortus?

e) Podać liczbę dzieci nieślubnych w ostatnich pięciu latach.

f) Czy znajdują się w parafii rozbite stadła małżeńskie (samowolne separacje) i z jakich powodów?, ile?

g) Czy zdarzają się w parafii wypadki życia na wiarę - jakie tego powody jak reaguje opinia, czy są środki zaradcze?.

Każda z kart została w prawym górnym rogu opatrzona liczbą 3 wypisaną na tej samej maszynie do pisania, na której została sporządzona dana karta. Istnienie tej liczby sprawiało problem na etapie paginacji w archiwum. Kilkakrotnie archiwista brał ją mylnie za numer kolejny karty i powielał, wprowadzając paginację ołówkiem, co musiał później przekreślić i wprowadzić właściwy, kolejny numer karty w wiązce. Może to świadczyć o tym, że na etapie opracowywania tego dokumentu w archiwum pochodzenie nadrukowanej na każdej karcie liczby 3 nie było znane i nie było łączone z numerem rozdziału ankiety z $1930 \mathrm{r}$.

Być może z tego samego powodu całej jednostce został nadany nieprecyzyjny tytul, zacierający informacje o pierwotnym pochodzeniu dokumentacji: Ankieta duszpasterska dotyczaca moralności rodzinnej 1920-1929. Podane daty skrajne całej jednostki archiwalnej odpowiadają datom wykazu dzieci urodzonych W otwierającej kartotekę parafii Białogon. W wykazie dotyczącym tej parafii nie podano liczby urodzeń z 1914 r., ponieważ ona wówczas jeszcze nie istniała ${ }^{21}$. W wykazach urodzeń innych parafii, erygowanych przed 1914 r. taka informacja dostała zamieszczona zgodnie z wymogami ankiety z $1930 \mathrm{r}$.

Kwestię związku omawianej kartoteki o sygn. OD 17/4 z ankietą z 1930 r. ostatecznie rozwiązuje treści kilku wyjątkowych kart w tym zbiorze. Na karcie nr 60 dotyczącej parafii Michałów znajdujemy fragment listu jej tymczasowego administratora i równocześnie proboszcza sąsiedniej parafii Młodzawy ks. A. Gąbki, który został przepisany przez sporządzającego kartotekę. Przepisany został nawet nagłówek: Do Komisji Wiary i Obyczajów. Ksiądz A. Gąbka usprawiedliwiał się w nim z nieprzesłania ankiety z parafii, której był administratorem, stwierdzając:

Niniejszym komunikuję, że jako chwilowy administrator parafii Michałównie nie mogę przesłać ankiety duszpasterskiej tejże parafii, ponieważ nie znam stosunków parafialnych i żadnych statystyk nie posiadam.

W lewym dolnym rogu tym samym pismem maszynowym zamieszczono datę 7 lipca 1930 r. Podobną informację znajdujemy na karcie nr 167 dotyczącej parafii Sokolniki: ,nowy proboszcz - parafii nie zna”.

${ }^{21}$ G. Bujak, Parafie $w$ diecezji kieleckiej i ich obsada w okresie międzywojennym (1918-1939), Kielce 2009, s. 23. 
Na uwagę zasługuje treść karty 87 (pisownia oryginalna):

Przede wszystkim mam zaszczyt Prześwietnej Kurii zaznaczyć, że Rogów wszelkie papiery starannie odrabia... więc też i z „Ankietą Duszpasterską" styczniową, we właściwym czasie się załatwił. Czasami się jednak zdarza, że ulotni się jakiś papier... jak na przykład „wiersz powitalny” - „Gazety Tygodniowej”. Następnie ekscytacja do zalegających z „Ankietą" probostw zarządzona. Najpokorniej też przepraszam Wysoką Kurię za spóźnione sprawozdanie z Konferencji Dekanalnej, które przy niniejszym załączam. Wstyd doprawdy, ale komu? - będę musiał na ten temat $\mathrm{z}$ W. X. Dyrektorem pomówić. $Z$ najgłębszym szacunkiem X. Dworak.

$Z$ treści tej karty wynika, że między proboszczem Rogowa ks. F. Dworakiem a ks. Z. Pilchem z Komisji wiary i obyczajów miała miejsce wymiana korespondencji, w której kurialista, jak można sądzić, w ostrych słowach ponaglał starszego, zasłużonego proboszcza i dziekana, aby ten wypełnił nałożony na niego obowiązek. Biorąc pod uwagę znaczny rozmiar ankiety i krótki termin na nadsyłanie odpowiedzi, liczba konfliktów wynikających z tego mogła być większa, jednak brak informacji w źródłach nie pozwala określić rozmiarów zjawiska.

Wydaje się, że większość księży w końcu jednak wywiązała się z obowiązku i nadesłała odpowiedzi. Możemy tak wnioskować z liczby kart w kartotece o sygn. OD 17/4. W roku $1930 \mathrm{w}$ diecezji kieleckiej było 223 parafie ${ }^{22}$. Liczba kart $\mathrm{z}$ odpowiedziami merytorycznymi w omawianym fascykule to 203. Można zatem wnosić, że tylu duchownych wywiązało się z obowiązku udzielenia odpowiedzi na część trzecią ankiety.

Dodatkowych wskazówek na temat terminowości nadsyłania odpowiedzi na ankietę możemy szukać w samej kartotece. Wynika z niej, że opracowanie trzeciej jej części z 1930 r. przebiegało w kilku etapach. Większość kart przepisano na tej samej maszynie do pisania, na kartach zbliżonego formatu i te zostały zaopatrzone w prawym górnym rogu wspomnianym numerem 3 odpowiadającym numerowi działu ankiety. Jednakże 22 karty posiadają pod numerem 3 dodatkową informację w postaci skrótu umieszczonego w nawiasie (skr), który następnie został przekreślony. Karty te są węższe, jakby odcięte $\mathrm{z}$ większego arkusza, sporządzone mniej dokładnie i zostały spisane na różnych maszynach do pisania. Być może w miarę napływania zaległych ankiet, odpowiednie karty powstawały w późniejszym terminie. Opatrywano je numerem 3 odpowiadającym rozdziałowi ankiety będącym jednocześnie numerem działu kartoteki, do którego miały być dołączane, a także skrótem (skr), który przekreślano po umieszczeniu karty we właściwym miejscu.

Nie wiemy, czy księża odpowiedzieli na wszystkie pytania ankietowe ani jaka była głębia podanych informacji. Większość kart w kartotece o sygnaturze OD $17 / 4$ zawiera pełne informacje dotyczące liczby urodzin. Zostały one zapewne przepisane przez proboszczów wypełniających ankietę z rocznych podsumowań w parafialnych księgach zawierających akty chrztów, ale była to najprostsza część odpowiedzi. Wiele kart zawiera interesujące informacje będące odpowiedziami na pozostałe pytania ankiety z 1930 r. Liczbę tych odpowiedzi można oszacować

\footnotetext{
${ }^{22}$ Elenchus (1930), s. 89-93.
} 
na ponad $80 \%$. Dają one zatem podstawę nie tylko do egzemplifikacji poruszanych problemów, lecz także ich ilościowego ujęcia.

Pojawia się pytanie, czy ks. Z. Pilch planował opracowanie w podobnej formie kartoteki wszystkich 11 rozdziałów ankiety z 1930 r.? Nie wiemy, czy pozostałe fragmenty zostały opracowane, ale zaginęły, czy kontynuację opracowania przerwano. Nie wiemy, dlaczego omawiany fascykuł przetrwał jako odrębna jednostka archiwalna ani co stało się z oryginałami ankiet. Po śmierci ks. Z. Pilcha w 1962 r. większość jego spuścizny uległa zniszczeniu. Nie wiemy, czy znajdowały się w niej także oryginały ankiety z 1930 r. i ewentualne opracowane jej kolejne fragmenty.

Omawiana kartoteka sygn. OD 17/4 funkcjonuje obecnie jako odrębna jednostka archiwalna i naukowcy korzystają z niej do dziś. Do najważniejszych badań prowadzonych na jej podstawie należy zaliczyć publikacje R. Renz ${ }^{23}$.

\section{Sprawozdanie duszpasterskie za $1930 \mathrm{r}$.}

W grudniowym numerze KPD z 1930 r. ukazało się ogłoszenie wzywające księży do sporządzenia sprawozdania duszpasterskiego za rok $1930^{24}$. Miało ono polegać na wypełnieniu drukowanego formularza załączonego do numeru pisma. Ogłoszenie nie zostało podpisane, ale zamieszczenie go w oficjalnym miesięczniku diecezji nadawało mu urzędowy charakter. Jako termin nadsyłania sprawozdań wyznaczono koniec stycznia następnego roku. W ogłoszeniu została określona droga służbowa przesyłania ankiet. Proboszczowie mieli to zrobić nie bezpośrednio na adres kurii, ale „za pośrednictwem Księży Dziekanów”. W ogłoszeniu znalazła się też wskazówka dla kierowników dekanalnych struktur następującej treści: „Przewielebni Księża Dziekani, dla uniknięcia kłopotliwych ponagleń od razu przypilnują, aby sprawozdania były nadesłane ze wszystkich parafii”25.

Ten krótki komunikat pozwala na sformułowanie kilku wniosków. Po pierwsze, jego powściągliwa, a nawet oschła forma, odmienna, od pełnej entuzjazmu zachęty do nadsyłania ankiet duszpasterskich ze stycznia 1930 r. mogła być wynikiem napięć, jakie miały miejsce w związku z egzekwowaniem tego pierwszego opracowania. Po drugie, zamieszczenie gotowego formularza w postaci druku o wiele bardziej precyzyjnie określało wymagania stawiane przed proboszczami niż nieokreślony, rozległy i niosący ryzyko wielu niepewności formularz 100 pytań ze stycznia. Po trzecie - ustalenie drogi służbowej dla przesyłania sprawozdań, w przeciwieństwie do sposobu bezpośredniego nadsyłania ankiet ze stycznia, zdejmowało z komisji kurialnej nieprzyjemny obowiązek kierowania upomnień o przestrzeganie wyznaczonych terminów i nakładało na dziekanów obowiązek dyscyplinowania kleru dekanalnego w tym zakresie.

${ }^{23}$ Wśród wielu opracowań tej autorki należy zwrócić uwagę na artykuł: R. Renz, Kobiety a planowanie rodziny $w$ latach międzywojennych (w świetle źródet kościelnych z Kielecczyzny), w: Kobieta i kultura życia codziennego wiek XIX i XX, red. A. Żarnowska, A. Szwarc, Warszawa 1997, s. 115-122.

${ }^{24}$ Sprawozdanie duszpasterskie za rok 1930, KPD, 17 (1930) z. 12, s. 311.

${ }^{25}$ Tamże, s. 311. 
O tym, że za organizacją sprawozdania stała Komisja wiary i obyczajów, dowiadujemy się $\mathrm{z}$ dokumentacji zachowanej w ADK. W poszycie OD $11 / 2^{26}$ znajdujemy wzór pisma z upomnieniem kierowanego do księży proboszczów, którzy - jak z tego wynika - w pewnej liczbie nie nadesłali odpowiedzi na czas. Pismo nosi datę 23 lutego 1931 r. i ma formę druku sporządzonego na powielaczu, w którym adres sformułowano: „Do W. Księdza Proboszcza w...”. W miejsce to miała zostać wstawiona nazwa parafii, z której sprawozdanie nie dotarło na czas. W nagłówku pisma jako nadawca została wymieniona: „Kuria Diecezjalna w Kielcach. Komisja Wiary i Obyczajów”. Pismo zostało podpisane przez ks. Z. Pilcha i kanclerza kurii ks. A. Źrałka. Nie ulega zatem wątpliwości, że za inicjatywą przeprowadzenia ankiety stała ta właśnie komisja kurialna. W treści pisma przypomniano proboszczowi o niedotrzymaniu terminu nadesłania wypełnionej ankiety, wyznaczano nowy termin do 31 marca $1931 \mathrm{r}$. i przesyłano dodatkowy blankiet sprawozdania duszpasterskiego ${ }^{27}$.

Druk sprawozdania, jaki został załączony do numeru KPD z grudnia 1930 r., miał format nieco większy niż A4. Na górze zawierał tytuł: „Rok P.[ański - GB] 1930. Sprawozdanie Duszpasterskie", pod którym w wyznaczone miejsca należało wpisać nazwę parafii i dekanatu. Pytań było 18 i nie były one numerowane. Dzieliły się na dwie grupy, wydzielone jedynie układem graficznym. W pierwszej części znajdowało się 5 pytań, na które odpowiedź wymagała podania wyłącznie wartości liczbowych:

Jaka liczba urodzonych w r. 1930-tym (ślubnych, nieślubnych);

Jaka liczba przystępujących do 1-ej komunii (chłopców, dziewcząt);

Ile było w roku sprawozdawczym ślubów? Ile było zgonów?;

Ile (przypuszczalnie) osób nie przystąpiło do spowiedzi wielkanocnej?;

Ile było w roku udzielonych Komunii (na podstawie obliczeń Renovatio Sanctissimi)?

Druga grupa złożona z 13 pytań dawała możliwości udzielenia obszerniejszych odpowiedzi:

Czy nie zaszły jakie zmiany we frekwencji wiernych na ranne msze i sumę w niedzielę i święta?;

Czy nie były w tym roku szerzone jakie błędy przeciwko wierze?;

Czy nie pojawili się jacy agitatorzy lub wyznawcy sekt?;

Czy nie było jakich nawróceń?

Czy nie zdarzyły się jakie skandale w życiu parafii?;

Jakie były tematy kazań rannych?;

Jakie były tematy kazań na sumie?;

W jakiej formie odbyły się rekolekcje postne? Kto je prowadził?

Jakie było przygotowanie do uroczystości św. Stanisława Kostki?

Ile było wyjazdów w niedziele i święta na odpusty (z kazaniem, ze sumą, do słuchania spowiedzi)?;

Ile godzin religii w szkole ma ks. proboszcz, ile wikary?;

26 ADK, Akta Kurii Diecezjalnej Kieleckiej, Sprawozdanie duszpasterskie za rok 1930 [dodane kilka referatów o duszpasterstwie], sygn. OD 11/2.

27 ADK, sygn. OD11/2, k. 2. 
Jaki stan kolportażu pism katolickich w porównaniu z rokiem ubiegłym?;

Czy nie zaszły jakie ważniejsze wydarzenia w parafii? (o misjach opowiedzieć osobno).

Zachowały się tylko 22 oryginały wypełnionych sprawozdań. Wraz z innymi materiałami tworzą one w ADK jednostkę o nazwie „Sprawozdanie duszpasterskie za rok 1930", sygn. OD11/2. Liczy ona 95 nienumerowanych kart. Zachowane oryginały sprawozdań zostały wypełnione pismem ręcznym, maszynowo wpisano tylko nazwę parafii i dekanatu. Być może dokonano tego na polecenie kurii, przygotowując do ekspedycji grudniowy numer KPD do konkretnych parafii. Siedem formularzy zawiera własnoręczne podpisy proboszczów. Zostały one opatrzone prezentą w kancelarii kurii. Jak z tego wynika, zachowana część sprawozdań wpłynęła w większości na przełomie stycznia i lutego $1931 \mathrm{r}$. Są to zatem formularze, które zostały nadesłane w pierwotnie wyznaczonym terminie.

Mimo że nie zachowały się oryginały wszystkich sprawozdań, ich treść możemy z dużą dokładnością odtworzyć, opierając się na pozostałej zawartości jednostki archiwalnej OD 11/2, złożonej ze zbiorczych zestawień odpowiedzi zawartych we wszystkich nadesłanych sprawozdaniach (k. 25-95).

Opracowania te sporządzono $\mathrm{z}$ podziałem na dekanaty i parafie. Zawierają one zarówno dane liczbowe, jak i przepisane fragmenty odpowiedzi o charakterze opisowym. Te ostatnie z braku miejsca zamieszczano w formie skrótów. Na podstawie porównania $\mathrm{z}$ zachowanymi formularzami wydaje się, że w miarę wiernie oddają one, treść udzielanych odpowiedzi. $\mathrm{W}$ omawianym poszycie znajduje się 7 zestawień zbiorczych nazwanych „sprawozdaniami”:

1. Sprawozdanie duszpasterskie z kolportażu pism katolickich.

2. Sprawozdanie duszpasterskie zawierające ważniejsze wydarzenia w parafiach.

3. Sprawozdanie duszpasterskie omawiające błędy przeciw wierze, agitatorów i wyznawców sekt w poszczególnych parafiach.

4. Sprawozdanie duszpasterskie wykazujące nawrócenia i skandale w poszczególnych parafiach.

5. Sprawozdanie duszpasterskie zawierające tematy kazań rannych i na sumie.

6. Sprawozdanie duszpasterskie obejmujące urodzonych, komunikujących, zawierających małżeństwa i zmarłych.

7. Sprawozdanie duszpasterskie wykazujące ilość odbytych rekolekcji postnych.

Poszczególne „sprawozdania” łączą informacje z odpowiedzi udzielanych na różne pytania formularza sprawozdania duszpasterskiego z 1930 r. Są kompilacjami sporządzonymi zapewne w Komisji wiary i obyczajów na podstawie nadsyłanych odpowiedzi. Na przykład w sprawozdaniu nr 3 zebrano odpowiedzi z trzech odrębnych pytań formularza, a w sprawozdaniu $\mathrm{nr} 4 \mathrm{z}$ dwóch.

Najobszerniejsze pod względem informacyjnym jest sprawozdanie nr 1, dotyczące kolportażu prasy. Autor kompilacji zestawił dla każdej parafii tytuły kolportowanych w niej gazet i czasopism wraz z informacją o liczbie rozprowadzanych egzemplarzy, jeśli taka została podana przez proboszcza. Najmniej informacji 
znajdujemy w sprawozdaniu nr 3 dotyczącym błędów przeciw wierze i agitacji różnych sekt. Sporadycznie, choć w każdym dekanacie przynajmniej w jednej parafii, odnotowano obecność badaczy Pisma św. W dekanacie jędrzejowskim, w którym istniała lokalna schizma ks. Andrzeja Huszno ${ }^{28}$, proboszczowie informowali nie tylko o jej obecności, lecz także reakcji społeczności parafialnej, np. proboszcz parafii w Jędrzejowie stwierdzał: „Agitatorów Huszny ludność wypędzała”.

Każde z siedmiu sprawozdań było sporządzane na drukowanych wykazach parafii ułożonych $\mathrm{w}$ porządku dekanalnym i składało się z dziewięciu kart zadrukowanych jednostronnie, po których na osobnym, jednostronicowym druku zamieszczono podsumowania dla całych dekanatów. Podsumowania najczęściej zawierają zestawienia liczbowe, ale sporadycznie zdarzają się także informacje o charakterze merytorycznym.

Przykładowo z podsumowania dla sprawozdania nr 3 dotyczącego błędów w wierze wynika, że w 200 parafiach diecezji proboszczowie nie zgłaszali takich problemów, a sytuację przeciwną odnotowano w 13 parafiach. Agitacja sekt była obca wiernym w 180 parafiach, a odnotowano ją w 33 parafiach. Z podsumowania sprawozdania $\mathrm{nr} 4$ poświęconego nawróceniom i wydarzeniom zakwalifikowanym jako skandale nawrócenia odnotowano w 190 parafiach, a ich brak w 23. Skandale wykazywało 147 proboszczów, a ich brak 67.

Na uwagę zasługuje podsumowanie ostatniego sprawozdania nr 7 dotyczącego przeprowadzenia w parafiach rekolekcji w wielkim poście. Szczegółowy, dziewięciostronicowy formularz zbiorczy, tak jak w poprzednich sześciu sprawozdaniach, został wypełniony precyzyjnie i zawiera bogaty materiał informacyjny. Natomiast podsumowanie według dekanatów zostało przerwane po sporządzeniu go dla czterech pierwszych dekanatów z listy. Można przypuszczać, ze praca została przerwana, a autor już do niej nie powrócił.

Wyniki sprawozdania duszpasterskiego za 1930 r. zostały omówione w obszernym, anonimowym artykule na łamach $\mathrm{KPD}^{29}$. Znajdujemy w nim ważną informację o liczbie nadesłanych sprawozdań. Na wstępie autor informuje, że „8 proboszczów nie nadesłało sprawozdania”, przy czym sprawozdania z Bejsc i Brzezin „dostarczono później”. Jak można przypuszczać, już po napisaniu artykułu, ale przed jego wydrukowaniem, co umożliwiło uaktualnienie odnośnych informacji. Dowiadujemy się także, że nie wszystkie nadesłane sprawozdania zostały wypełnione w całości. Braki w tym zakresie, bez podania szczegółów autor wskazał tylko dla liczby udzielonych w roku 1930 komunii św. (Renovatio Sanctissimi). Na podstawie siedmiu zachowanych w archiwum sprawozdań-zestawień wydaje się, że braki dotyczyły także innych udzielanych informacji. Po wojnie sprawozdanie duszpasterskie z 1930 r. nie było szerzej wykorzystywane przez badaczy.

${ }^{28}$ Cz. Lechicki, Huszno Andrzej, w: Polski Stownik Biograficzny, t. 10, red. Z. Abramowicz, K. Lepszy, Wrocław 1962-1964, s. 124.

${ }^{29}$ Stan religijno-moralny $w$ diecezji na podstawie sprawozdań duszpasterskich 1930, KPD, 18 (1931) z. 6-7, s. 182-186. 


\section{Podsumowanie}

Z przeprowadzonej analizy Ankiety duszpasterskiej z $1930 \mathrm{r}$. i Sprawozdania duszpasterskiego za rok 1930 wynika, że oba badania dotyczyły rozległej i zróżnicowanej problematyki życia społeczno-religijnego wiernych diecezji kieleckiej. Stanowiły ważny i nowoczesny, jak na swoje czasy, niestosowany w takim wymiarze wcześniej w diecezji kieleckiej i wyjątkowy również w skali ogólnopolskiej, instrument poznania i systematyzacji zagadnień związanych z szeroko rozumianą sytuacją religijną w parafiach. Mimo swoich braków warsztatowych były nowatorskim przykładem zastosowania narzędzi z zakresu warsztatu socjologicznego w szeroko rozumianej działalności duszpasterskiej. Pozwalały w określonym zakresie na ilościowe i jakościowe charakteryzowanie różnych przejawów religijności i związanych z nią problemów na poziomie parafii. Informowały m.in. o zakresie odbywania praktyk religijnych, ale także zagrożeniach agitacją o charakterze religijnym i politycznym. Wskazały zakres oddziaływania tradycyjnych form duszpasterstwa (kazania, rekolekcje, misje), jak i nowych (czytelnictwo prasy).

Istnieje podobieństwo między pytaniami z ankiety ze stycznia $1930 \mathrm{r}$. a pytaniami sprawozdania duszpasterskiego za 1930 r. Dotyczy ono nie tylko pierwszej, statystycznej części sprawozdania, ale także pozostałych 13 pytań. Być ks. Z. Pilch planował przeprowadzanie kolejnych sprawozdań jako metody uzupełniania $i$ aktualizowania planowanej przez siebie rozległej tematycznie diecezjalnej kartoteki dotyczącej zagadnień duszpasterskich i społecznych.

Nie możemy wykluczyć, że ks. Z. Pilch jako kierownik prac Komisji wiary i obyczajów docelowo dążył do sporządzenia takiej kartoteki i jej systematycznej aktualizacji. Taka kartoteka byłaby ważnym narzędziem w formowaniu programów duszpasterskich dla całej diecezji i realizacji celów nakreślonych w tym zakresie w statutach synodalnych z 1927 r. Braki w źródłach nie pozwalają jednak na weryfikację tej tezy ${ }^{30}$.

Narzędzie w postaci kartoteki było nowoczesną formą nadzoru i koordynacji wielu obszarów życia parafialnego. Taka kartoteka mogła być stosunkowo szybko aktualizowana przez przeprowadzane doraźnie tematyczne ankiety, dotyczące zagadnień, które $\mathrm{w}$ danym momencie interesowały władzę diecezjalną. $\mathrm{W}$ ten sposób można było badać zmiany różnych parametrów z zakresu religijności na poziomie parafii, będące np. skutkiem podejmowanych centralnie działań i w miarę potrzeby je korygować. Kartoteka i ankiety miały szansę stać się bardziej sprawnym instrumentem kontroli działalności duszpasterskiej niż tradycyjne wizytacje dziekańskie czy biskupie. Próba zaprowadzenia w diecezji takiej kartoteki wpisywała się, jako nowatorski system zarządzania i kontroli, w program odnowy życia religijnego w duchu nakazów synodu z 1927 r.

${ }^{30}$ Ks. Z. Pilch w wygłaszanych referatach z zakresu homiletyki chętnie korzystał z własnych badań ankietowych i sporządzanych na ich podstawie kartotek. Między innymi podczas zjazdu teologicznego w Kielcach wygłosił referat, w którym uwzględnił wyniki własnej ankiety przeprowadzonej dwa lata wcześniej w Paryżu w środowisku profesorów homiletyki z Europy Zachodniej. Por. Olszewski, Ks. Zygmunt Pilch (1882-1962), s. 247. 
Tym większe zdziwienie budzi fakt rezygnacji z tego instrumentu. Omówione ankieta i sprawozdanie były ostatnimi badaniami podjętymi na taką skalę przez Komisję wiary i obyczajów. Brak też jest informacji o wykorzystywaniu zgromadzonych w ich wyniku informacji w pracy kurii i jej wydziałów ${ }^{31}$.

Brak źródeł nie pozwala na udzielenie jednoznacznej odpowiedzi, dlaczego tak się stało. Być może przyczyny zaistniałej sytuacji należy łączyć z jaką̧ś istotną zmianą samej wizji duszpasterstwa w diecezji kieleckiej. Jak się jednak wydaje, przyczyny takiej zmiany nie należy upatrywać w sytuacji wewnętrznej diecezji. Ustalona na synodzie w 1927 r. linia odnowy działalności duszpasterskiej została wyraźnie nakreślona i utrwalona w statutach, a reorganizacja struktury kurii poprzez powołanie Komisji wiary i obyczajów oraz działania podjęte przez tę komisję z omówionym rozmachem i zaangażowaniem wskazują na pełne poparcie bpa A. Łosińskiego dla tego kierunku.

Szukając natomiast tych przyczyn poza diecezją, należy wskazać na rozwój ogólnopolskiego programu odnowy duszpasterskiej i skorelowanych z nim struktur, procedur i narzędzi działania w postaci Akcji Katolickiej. Rozwijająca się od dłuższego czasu idea zorganizowania działalności katolików świeckich w struktury oparte na zalecaniach Piusa XI zawartych w Ubi arcano Dei z 1922 r. natrafiała na istniejące i rozwijane w wielu diecezjach odmienne modele. Nawiązywały one silniej do lokalnych zwyczajów, przyzwyczajeń i możliwości, sięgających niekiedy korzeniami czasu zaborów. Ostatecznie zatwierdzenie przez Piusa XI statutu polskiej Akcji Katolickiej w listopadzie 1930 r. nadała temu projektowi sankcję papieską, w której obliczu dotychczasowe lokalne inicjatywy musiały ustąpić i ulec reorganizacji32.

Po zaprowadzeniu w diecezji kieleckiej Akcji Katolickiej centrum wysiłku na rzecz odnowy społeczno-religijnej przesunęło się do Diecezjalnego Instytutu Akcji Katolickiej (dalej: DIAK) powołanego przez bpa A. Łosińskiego 19 września $1931 \mathrm{r}^{33} \mathrm{~W}$ swoich działaniach na rzecz odnowy społeczno-religijnej w diecezji DIAK uwzględniał nowe kierunki o charakterze ogólnopolskim powstające w Naczelnym Instytucie Akcji Katolickiej (dalej: NIAK). DIAK w realizacji swoich zadań posługiwał się również badaniami ankietowymi, jednak nie w takiej skali jak

${ }^{31}$ Wyjątkiem były wspomniane artykuły opublikowane na łamach KPD po przeprowadzeniu ankiety i sprawozdania. Por. przypisy 19 i 29.

${ }^{32}$ Więcej na temat znaczenia papieskiego zatwierdzenia Statutu Akcji Katolickiej w Polsce dla podporządkowania sobie przez Akcję Katolicką w różnych diecezjach lokalnych inicjatyw w zakresie odnowy życia religijnego i społecznego wierzących zob. K. Krasowski, Episkopat katolicki w II Rzeczypospolitej. Myśl o ustroju państwa - postulaty - realizacja, Warszawa-Poznań 1992, s. 208213. Podobnie proces ten przedstawia Stanisław Wilk, wskazując działalność i interwencje nuncjusza w Warszawie podczas posiedzeń Konferencji Episkopatu Polski na rzecz realizacji programu papieskiego Akcji Katolickiej często kosztem lokalnych inicjatyw. Wątpliwości co do obranego kierunku i to przez długi jeszcze czas miało wielu biskupów, mimo że podporządkowali się oni woli Ojca św. Jednym z wyrazów manifestacji takich wątpliwości była rezygnacja abpa Adama Sapiehy z członkostwa w Komisji Episkopatu do spraw Akcji Katolickiej w 1935 r.. S. Wilk, Episkopat Kościoła katolickiego w Polsce w latach 1918-1939, Warszawa 1992, s. 256-260.

${ }^{33}$ Liebrecht, Biskup Augustyn Łosiński, s. 224. 
omówione badania ks. Z. Pilcha. DIAK najczęściej prowadził je w celu ustalenia możliwości, zakresu i metod realizacji programów inicjowanych przez NIAK ${ }^{34}$. Ks. Z. Pilch nie wszedł do grona organizatorów Akcji Katolickiej w diecezji kieleckiej, ale jego nazwisko pojawiało się, choć rzadko, w związku z inicjatywami DIAK. W latach 30. skupił się on głównie na pracy wykładowcy seminarium duchownego w Kielcach i rozwijaniu zapoczątkowanych przez siebie wcześniej licznych inicjatyw homiletycznych, którymi ostatecznie w największym zakresie utrwalił pamięć o sobie ${ }^{35}$.

\section{REFERENCES / BIBLIOGRAFIA}

\section{Źródła}

\section{Archiwalne}

Akta Kurialne Ogólne, Ankieta duszpasterska dotycząca moralności rodzinnej r. 19201029, sygn. OD $17 / 4$.

Akta Kurii Diecezjalnej Kieleckiej, Sprawozdanie duszpasterskie za rok 1930 [dodane kilka referatów o duszpasterstwie], sygn. OD 11/2.

\section{Drukowane}

Ankieta Duszpasterska, „Kielecki Przegląd Diecezjalny”, 16 (1930) nr 1, s. 12-19.

Elenchus venerabilis cleri saecularis ac regularis dioecesis kielcensis, (1930, 1931, 19401941).

Gielniewski E., Stan religijno-moralny młodzieży w parafiach naszej diecezji na podstawie materiałów z ankiety duszpasterskiej z 1930 r., „Kielecki Przegląd Diecezjalny”, 18 (1931) nr 12, s. 307-315.

Gielniewski E., Wady naszego Ludu w świetle duszpasterskiej ankiety zebranej w początkach ub. roku, „Kielecki Przegląd Diecezjalny”, 18 (1931) nr 5, s. 141-144.

Mirek F., Elementy spoleczne parafii rzymsko-katolickiej. Wstęp do socjologii parafii, Poznań 1928.

Sprawozdanie duszpasterskie za rok 1930, „Kielecki Przegląd Diecezjalny”, 17 (1930) nr 12 , s. 311.

Sprawozdanie z konferencji Ks.Ks. Dziekanów odbytej pod przewodnictwem Najdostojniejszego Arcypasterza z Kielcach 21 listopada 1929 r., ,Kielecki Przegląd Diecezjalny", 16 (1929) nr 12, s. 294-302.

Sprawozdanie ze zjazdu duszpasterskiego, „Przegląd Diecezjalny”, 11 (1924) nr 11-12, s. 246-251.

Stan religijno-moralny $w$ diecezji na podstawie sprawozdań duszpasterskich 1930, „Kielecki Przegląd Diecezjalny", 18 (1931), nr 6-7, s. 182-186.

Synodus dioecesana kielcensis 1927, Kielce b.r.w.

Zamojski W., Potrzeba czasu, „Przegląd Diecezjalny”, 5 (1917-1918) nr 1, s. 11-16.

\section{Opracowania}

Bujak Grzegorz, Parafie $w$ diecezji kieleckiej i ich obsada w okresie międzywojennym (1918-1939), Kielce 2009.

${ }^{34}$ Więcej informacji na temat rozwoju AK w diecezji kieleckiej i prowadzonej przez nią działalności w moim artykule: Praca społeczna $w$ diecezji kieleckiej $w$ świetle publikacji na łamach „Kieleckiego Przegladu Diecezjalnego” w latach 1926-1939. Zarys przemian, ABMK 108, (2017), s. 47-59.

${ }^{35}$ Olszewski, Ks. Zygmunt Pilch (1882-1962), s. 245-250. 
Bujak Grzegorz, Praca społeczna $w$ diecezji kieleckiej $w$ świetle publikacji na łamach „,Kieleckiego Przeglądu Diecezjalnego” w latach 1926-1939. Zarys przemian, „Archiwa Biblioteki i Muzea Kościelne”, 108 (2017) s. 47-59.

Bujak Grzegorz, Synody diecezjalne Kościoła katolickiego w Polsce w latach 1922-1931. Organizacja i problematyka uchwat, Kielce 2010.

Grabowski Ignacy, Prawo kanoniczne, Warszawa 1947.

Krasowski Krzysztof, Episkopat katolicki w II Rzeczypospolitej. Myśl o ustroju państwapostulaty - realizacja, Warszawa-Poznań 1992.

Krasowski Krzysztof, Biskupi katoliccy II Rzeczypospolitej. Stownik biograficzny, Poznań 1996.

Lechicki Cz., Huszno Andrzej, w: Polski Słownik Biograficzny, t. 10, red. Z. Abramowicz, K. Lepszy, Wrocław 1962-1964, s. 124.

Liebrecht Grzegorz, Biskup Augustyn Łosiński. Ordynariusz kielecki w latach 1910-1937, Kielce 2018.

Olszewski D., Ks. Zygmunt Pilch (1882-1962). Ogólnopolska działalność naukowa kieleckiego homilety, w: Kielce i kielczanie w XIX i XX wieku, red. U. Oettingen, Kielce 2005, s. 241-250.

Renz R., Kobiety a planowanie rodziny $w$ latach międzywojennych ( $w$ świetle źródet kościelnych z Kielecczyzny), w: Kobieta i kultura życia codziennego wiek XIX i XX, red. A. Żarnowska, A. Szwarc, Warszawa 1997, s. 115-122.

Szafrański A.L., Zarys dziejów teologii pastoralnej ogólnej (hodogetyki), w: Dzieje teologii katolickiej w Polsce, t. 3, wiek XIX i XX, cz. 2, red. M. Rechowicz, Lublin 1977, s. 225-242.

Wilk Stanisław, Episkopat Kościoła katolickiego w Polsce w latach 1918-1939, Warszawa 1992.

\title{
"PASTORAL SURVEY OF 1930" AND "PASTORAL REPORT FOR 1930" AND THE ROLE OF THESE DOCUMENTS IN THE PLANNED SOCIAL AND RELIGIOUS RENEWAL IN THE KIELCE DIOCESE DURING THE INTERWAR PERIOD
}

\begin{abstract}
This article reviews the preserved fragments of two questionnaire surveys conducted in the Kielce Diocese over the years 1930-1931 in the context of the religious renewal in that area after World War I. The measures implemented in this respect after 1918 were expressed to the fullest extend in the decisions of the diocesan synod of 1927 . One of its elements was to systematically observe the socio-religious changes by appointing a Commission of Faith and Customs in the curia. It was supposed to supervise the implementation of the synodal renewal plan in the Diocese. On the basis of surveys and other instruments, it was to determine the needs in respect of pastoral care at the level of the entire Diocese and individual parishes. Upon the establishment of the Catholic Action, which had been developed as a supra-diocesan organisation aimed at conducting a nationwide programme of religious renewal, the earlier local project was not continued. Consequently, the two questionnaire surveys discussed herein, much as they had not been fully preserved, constitute the most extensive testimonies thereof.
\end{abstract}

Keywords: Kielce Diocese; pastoral survey; interwar period; Fr. Zygmunt Pilch; social and religious life 